\title{
Governance Practices and Performance of Collective Organizations: Evidence from Self-Help Organizations in Siaya County, Kenya
}

\author{
Mr. Maurice Oluoch Onyango ${ }^{1,}$ Dr. Samson W. Mwangi ${ }^{2}$, Dr. Ng' etich Kibet ${ }^{3}$ \\ ${ }^{1}$ Assistant Lecturer, Department of Public Affairs \& Environmental Studies, Laikipia University, Kenya \\ ${ }^{2}$ Senior Lecturer, Department of Peace, Security and Social Studies, Egerton University, Kenya \\ ${ }^{3}$ Senior Lecturer, Department of Peace, Security and Social Studies, Egerton University, Kenya
}

\begin{abstract}
This study examined the relationship between governance practices and the performance of self-help help organizations in Siaya County, Kenya. This was a cross-sectional survey, which covered twenty seven help organizations, out of which 243 respondents were selected through stratified random sampling. Members of the self-help organizations were the primary respondents in the study. Data was collected by use of interview schedules and then analyzed using frequency counts and percentages. Pearson and Spearman Product Moment Correlations, and Chi-Square analysis were used to carry out further analysis of the data collected. General Systems theory and Collective Action theory were used to explain the operating environment of these groups, and why people join them respectively. There was a significant relationship between group size, size of groups' executive committees, election cycle, number of terms served by executive committees, incidences of disputes on the one hand and performance of self-help organizations in Siaya County of Kenya on the other hand. Understanding self-help organizations in terms of governance and performance is indeed significant at a time when communities through grassroots based organizations are increasingly being urged to take charge of their development needs. In terms of policy, this study recommends for the development of a national policy framework to regulate self-help organizations sector, and the establishment of financial and insurance institutions to handle financial and insurance needs of these organizations respectively.
\end{abstract}

Key Words: Governance, Performance, Practices, Self-help Organizations

\section{Introduction}

Kenya's contemporary collective organizations are traceable to colonial period [1] and [2], 1991). The colonial authorities replaced African societies' structures with a hierarchical administration, with the sole goal of entrenching colonial authorities to the grassroots as a means of not only maintaining law and order but also channeling development initiatives to the local communities [1]. The result of this he regrets was the disablement of traditional support systems and institutions. Failure by the independent and post-independent leadership to live its promise of tacking poverty, illiteracy and diseases did not only exacerbate human sufferings but also resulted in a huge development gulf that could only be filled by specially designed efforts outside the government and traditional support systems. Self-Help organizations therefore groups emerged to address some of the problems occasioned by the political decisions of colonial and post-independent leadership [1].

Other than its political decisions, the economic policies of the colonial regime, which changed the African economy from subsistence to dual one of commercialism and subsistence did not only elevate land as the factor of production but also and placed it under sole ownership of males [2]. The implication of these economic decisions were that women and other landless groups apart from being shut out of formal channels of development were also condemned to work as manual labourers in agricultural farms. Left with no choice, majority of the landless and women thus resorted to Self-help work a source of livelihood.

Kenya started experiencing self-help groups as early as late 1950s. But this was not the case with Siaya County. Self-help groups in the County date back to mid 1970s. The County (formerly Siaya district) had about 20 registered self-help groups by 1979. Presently there are over 6000 registered self-help groups [3] and [4], implying that about $25 \%$ or over 120,000 of the County's population are directly involved in formal self-help work. Whereas the numbers of self-help groups in Siaya County have grown by nearly $30,000 \%$ in the last four and a half decades, poverty levels in the same period rose from $24 \%$ to $50 \%$ representing $108 \%$ rise [5] and [6]. The population of the district that had access to piped water and electricity for lighting stood at a mere $5.1 \%$ and $2.9 \%$ respectively by the year 2002 [7]. Siaya County is food secure for only four months in a year owing to poor crop yields and insufficient arable land [8]. In terms of household expenditure, among other 
expenditures a household in the County spends an average of Kshs 3,148.00 per month on medication, which higher than the national average of Kshs 1,990.00, and is only second to Kshs 6,280.00 of Nairobi County [9].

From the foregoing, it is apparent that the growing numbers of self-help organizations have not helped much in reversing the tide of deteriorating human conditions in Siaya County. The present study was aware of the existence of other development agencies in the district and noted that self-help organizations alone could not shoulder blame for low standards of living in Ugenya constituency. However, the current study reiterates that the constituency would have had a better human development indices had self-help organizations, which served directly over $25 \%$ of the constituency's population got their priorities right. Accordingly, the present study was informed by the need to understand why the rising numbers of self-help organizations in the constituency had not resulted in significant improvement in human living conditions. This was achieved by examining the role of governance practices on the performance of self-help organizations in Siaya County, Kenya. Indeed poor governance has been found to be a major stumbling block to development. Understanding self-help organizations in terms of governance practices becomes even more necessary now that communities and their organizations are increasingly being urged to take charge of their development.

\section{Study Objectives}

This study sought to (1) examine the relationship between size of executive committee self-help and performance of self-help organizations; (2) assess whether election cycle had any significant bearing on the performance of self-help organizations; (3) analyze the link between number of terms served by executive committee members and performance of self-help organizations; (4) establish whether incidences of disputes influenced performance of self-help organizations.

\section{Methodology}

3.1 Research Design: This study was done in Siaya County, Kenya. The study used cross-sectional survey design. The design does not only allow for the selection of either the entire population or a subset as study respondents, but also allows the elicitation of standardized responses through the use of standardized instruments such as questionnaires or interviews schedules [10], [11], [12], [13]. This study designed an interview schedule with standardized questions, and then administered to 236 respondents. Though critics of survey studies argue that the study of smaller number of cases does not provide good grounds for generalization of findings, however, this limitation could be overcome with detailed study of the real issues and problems [14]. Like other complex social phenomena, the activities of self-help organizations and the behaviours of their members called for the use Cross-section study design, which allows detailed study and analysis of the situation.

3.2 Sampling Methods: Stratified random sampling was used to select the organizations and respondents. Stratification was based on the organizations' sub-group, activities, administrative location and members' position. The study then proceeded to select $10,9,8$ women, mixed and youth groups respectively. Organizations were also picked depending on their activities, which included those engaged in farming, public transport, hospitality, construction and environmental conservation sectors. To ensure broad spread, groups were picked from each of the 11 administrative locations of the constituency. Members were stratified into ordinary and executive committee members to ensure broad and equitable engagement of members of self-help groups in the study. The study then selected a total of 9 members per group; comprising of 3 executive committee members and 6 ordinary members. Self-help Organizations in Ugenya constituency were estimated to have 50,000 . Consideration for study was given to 1290 self-help organizations and 25,600 members. This being the number of organizations that had at least three years of operational experience. Using Taro Yamane's formula [15] and [13] formula, the study then selected 27 self-help organizations and 243 respondents.

3.3 Data Collection Instruments and Procedures: Interview schedule was the main instrument of data collection. It was preferred as it allows for clarifications where desired [16]. Interview schedules also offered the researcher the opportunity to interact with sampled respondents, a move that ensured that up to 236 out of the anticipated 243 respondents turning up and responding to the questions. Administering the questions directly to the respondents was also a significant step at minimizing possible dishonesty that could have arose had the respondents been left on their own to respond to the questions.

3.4 Data Analysis: Descriptive and inferential statistics were used to analyze data. Descriptive statistics used were frequencies, percentages and mean. Size of executive committee, election cycle and number of terms were all measured at interval, with Pearson Correlation used to test the relationship between each of them at organizational performance. Disputes were measured at nominal level, with Chi-square used to test the association between it and performance. 
4.1 Organizations' Profile

\section{Results}

4.1.1 Sub-Group: Self-help organizations are categorized into women, mixed and youth groups. The present study covered 236 respondents drawn from youth, women and mixed groups, which accounted for $38 \%, 30 \%$ and $32 \%$ of the organizations respectively as TABLE 1.1 below shows.

Table 1.1: Organizations' Sub-Group

\begin{tabular}{|l|r|r|}
\hline Sub-Group & Frequency & Percent \\
\hline Youth Group & 72 & 30 \\
Women Group & 90 & 38 \\
Mixed Group & 74 & 32 \\
Total & 236 & 100.0 \\
\hline
\end{tabular}

Organizations' Age: This study covered organizations with between 1 and 24 years operational experience. The oldest and youngest groups were aged about 24 years and 3 years respectively (TABLE 1.2 below).

Table 1.2: Age of Organizations

\begin{tabular}{|l|l|l|}
\hline Operational Years & Frequency & Percent \\
\hline $1-4$ Years & 26 & 11 \\
\hline 5-9 Years & 110 & 47 \\
\hline 10-14 Years & 68 & 26 \\
\hline 15-19 Years & 15 & 8 \\
\hline $20-24$ Years & 15 & 8 \\
\hline Total & 236 & 100 \\
\hline
\end{tabular}

4.1.2 Objectives: Organizations' main objective was to improve members' and close dependants' living standards; with specific focus on poverty reduction, economic empowerment, education of dependants and psycho-social support, all accounting for $15 \%, 52 \%, 15 \%, 11 \%$ and $7 \%$ of all objectives respectively as TABLE 1.3 below shows.

Table 1.3: Objectives of Self-help Organizations

\begin{tabular}{|l|l|l|}
\hline Objective & Frequency & Percent \\
\hline Psycho-Social Support & 17 & 7 \\
\hline Poverty Reduction & 35 & 15 \\
\hline Education of Dependants & 26 & 11 \\
\hline General Welfare & 35 & 15 \\
\hline Economic Empowerment & 123 & 52 \\
\hline Total & 236 & 100 \\
\hline
\end{tabular}

4.1.3 Activities Undertaken: Self-help groups surveyed had invested in various income generating activities. They included flour milling, vegetable farming, public transport (motor Cycle), poultry farming, fish farming, event management and outdoor catering (TABLE 1.4 below).

Table 1.4: Activities Undertaken by Self-Help Organizations

\begin{tabular}{|l|l|l|}
\hline Activity & Frequency & Percent \\
\hline Flour Milling & 17 & 7 \\
\hline Vegetable Farming & 17 & 7 \\
\hline Public Transport & 9 & 4 \\
\hline Poultry Farming & 45 & 19 \\
\hline Fish Farming & 17 & 7 \\
\hline Event Management & 26 & 11 \\
\hline Catering Services & 9 & 4 \\
\hline Various & 96 & 41 \\
\hline Total & 236 & 100 \\
\hline
\end{tabular}

All groups surveyed had maintained the same activities since their inceptions; a move they considered to be vital in maintaining members' commitment to the organizations. Although maintaining same activities for a relatively longer period of time was important in gaining members' commitment to organizations' ideals, the current study is of the view that modifying the activities was significant in re-orienting organizations' focus to the changing human tastes. 


\subsection{Governance Practices in Self-help Organizations}

4.2.1 Election of Leadership: Members of the executive committee were chosen through elections, with secret ballot, queuing and acclamation being used the election methods. These three methods of voting were given different approvals to results in TABLE 1.5 below.

Table 1.5: Respondents' Rating of Voting Methods

\begin{tabular}{|l|r|r|r|r|}
\hline Method & Approval & Disapproval & Don't Know & Total \\
\hline Secret Ballot & $92 \%$ & $6 \%$ & $2 \%$ & $100 \%$ \\
Queuing & $2 \%$ & $96 \%$ & $2 \%$ & $100 \%$ \\
Acclamation & $6 \%$ & $93 \%$ & $1 \%$ & $100 \%$ \\
\hline
\end{tabular}

4.2.2 Considerations in the choice of leadership: Education was the greatest consideration when electing executive committee members. This was followed by aspirants' gender, membership duration, economic and professional background each accounting for $15 \%, 14 \%, 11 \%$ and $10 \%$ respectively. Other considerations going by the results in TABLE 1.6 below were aspirants' age, family background, clan and religious affiliation.

Table 1.6: Considerations in the Choice of Leadership

\begin{tabular}{|l|l|l|}
\hline Factors Considered & Frequency & Percent \\
\hline Profession & 24 & 10 \\
\hline Religion & 8 & 2 \\
\hline Clan & 12 & 5 \\
\hline Membership Duration & 33 & 14 \\
\hline Economic Status & 12 & 5 \\
\hline Age & 16 & 7 \\
\hline Gender & 35 & 15 \\
\hline Education & 76 & 32 \\
\hline Total & 236 & 100 \\
\hline
\end{tabular}

4.2.3 Election Supervisions: This study established that elections in self-help organizations were presided over by three offices namely- DSSO, chiefs and sponsors. DSSO, chiefs and sponsors presided over $84 \%, 8 \%$ and $8 \%$ respectively of the organizations' elections, and their independence were confirmed by $92 \%, 5 \%$ and $3 \%$ of the respondents respectively (Fig 1.1 below).

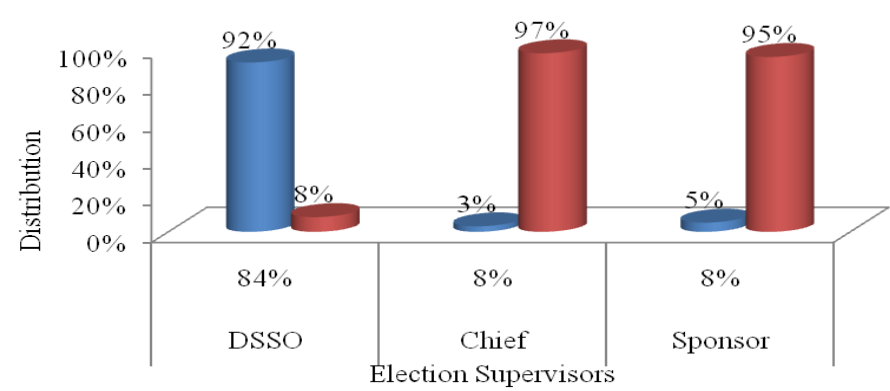

- Independent

- Partisan

Figure 1.1: Distribution of Election Supervisors and their Independence

4.2.4 Election Cycles: While most of the organizations held elections after every 2-3 years, others had elections done annually with some taking as long as four years. But these were done at times against the wishes of members of the organizations if results in Fig 1.2 are anything to go by.

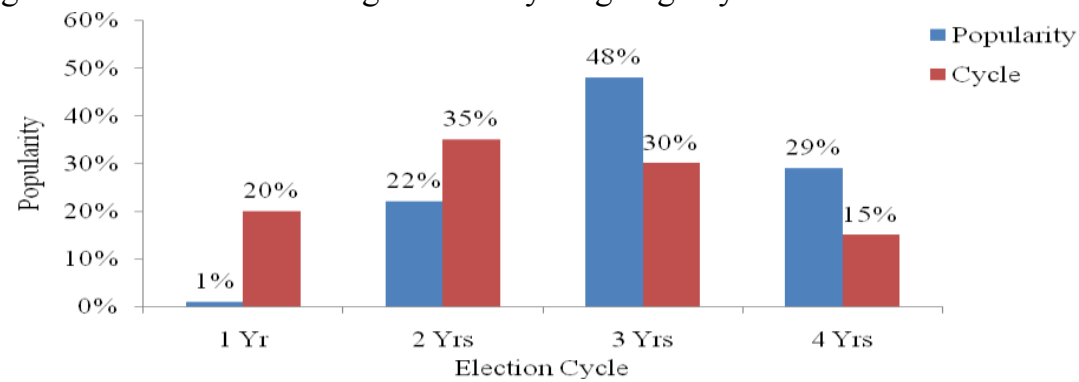

Figure 1.2: Distributions of Respondents' Approval of Election Cycles 
4.2.5 Religious Composition of Leadership: Leaders in all positions appeared to have strong Roman Catholic and ACK roots as TABLE 1.7 below shows. For instance over $90 \%$ of the respondents noted that their chairpersons professed either Roman Catholic or ACK faith. Similarly, $90 \%$ and $85 \%$ of positions of secretary and treasurer belonged to Catholic and ACK faiths respectively.

Table 1.7: Religion of Executive Committee Members

\begin{tabular}{|c|c|c|c|c|}
\hline \multirow{2}{*}{ Position } & \multicolumn{3}{|c|}{ Religion } & \multirow{2}{*}{ Total } \\
\cline { 2 - 4 } & Roman Catholic & ACK & Evangelicals & \\
\hline Chairperson & $13(52 \%)$ & $10(40 \%)$ & $2(8 \%)$ & $25(100 \%)$ \\
Secretary & $14(56 \%)$ & $10(40 \%)$ & $1(4 \%)$ & $25(100 \%)$ \\
Treasurer & $12(48 \%)$ & $10(40 \%)$ & $3(12 \%)$ & $25(100 \%)$ \\
\hline
\end{tabular}

4.2.6 Gender Representation in Leadership: The results in Fig 1.3 below show that women dominated all positions of leadership in self-help organizations. There were $64 \%$ of women serving as chairpersons compared to $36 \%$ of males. In the position of secretary, women occupied $68 \%$ of the positions compared to $32 \%$ for men, with similar trends obtaining for treasurer's positions where women occupied $88 \%$ of the positions, compared to $12 \%$ for men.

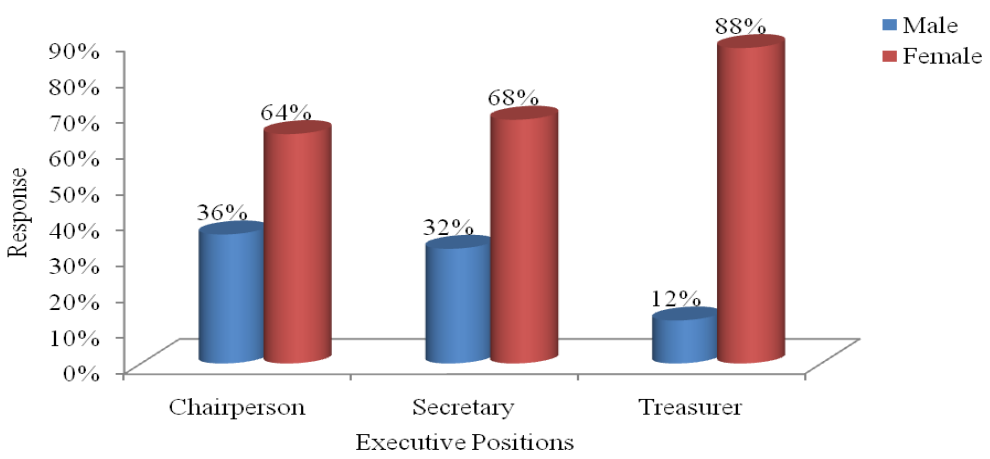

Figure 1.3: Gender Representation in the Executive Committees

4.2.7 Education Levels of Executive Committee Members: The position of secretary appeared to have been reserved to members with primary and secondary levels of education, where $93 \%$ and $7 \%$ of its occupants had secondary and primary level of education respectively. Aspirant's level of education was not a key requirement for the chairperson's position as Fig 1.4 below shows.

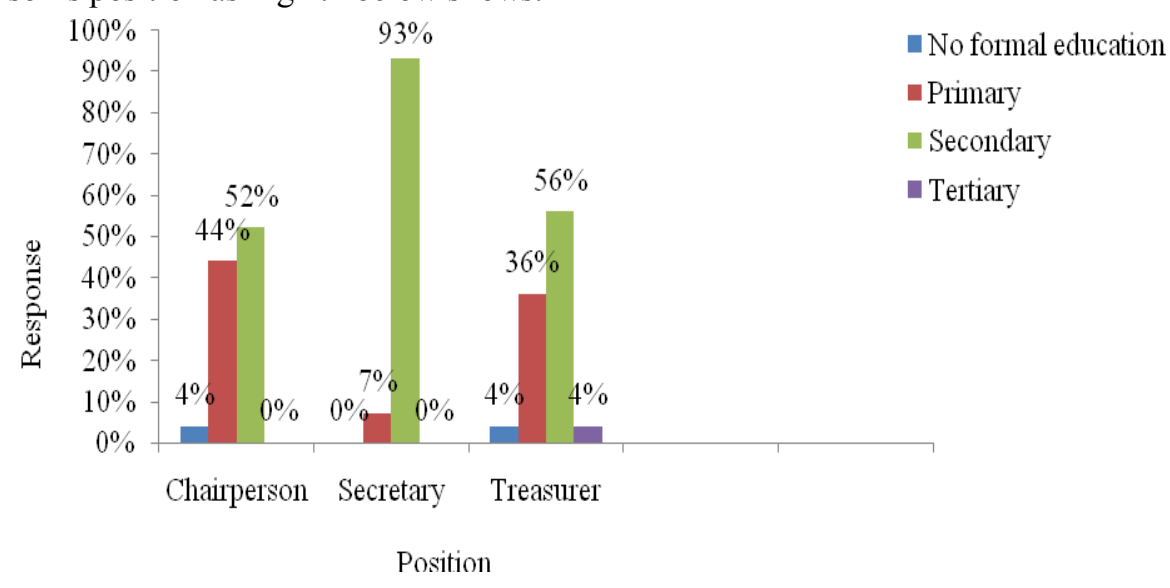

Figure 1.4: Levels of Formal Education of Executive Committees Members

4.2.8 Age Distribution in Organizational Leadership: Results presented in Fig 1.6 below suggest that selfhelp organizations surveyed preferred younger persons in its leadership as $41 \%$ of their leaders were drawn from the age bracket of 40-50 years. This was followed by the age bracket of $29-39$, which accounted for $29 \%$ of the entire leadership, with persons aged over 61 years being the least considered for leadership positions. 


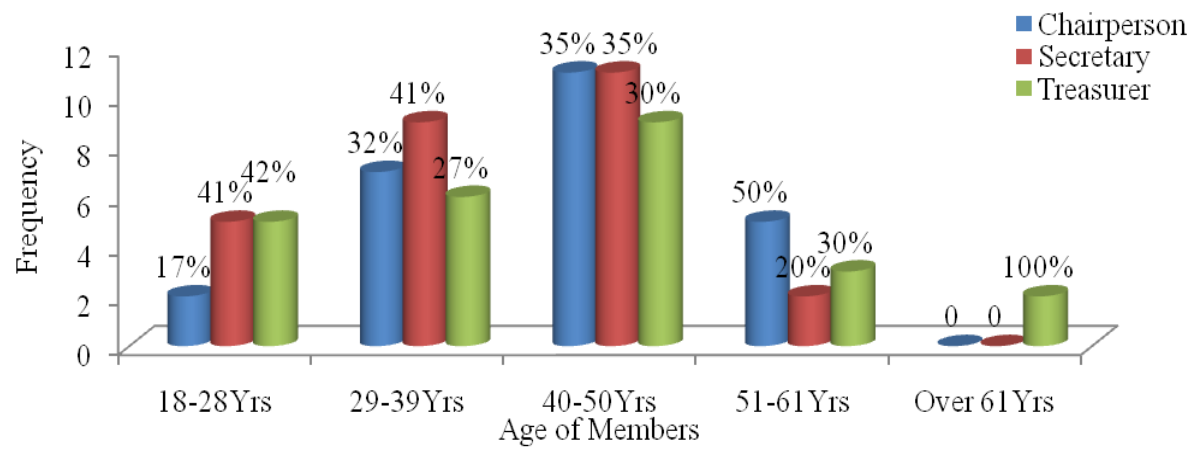

Figure 1.6: Age Distribution of Executive Committees Members

4.2.9 Size of Executive Committees: Self-help organizations surveyed had over three positions in their executive committees despite statutory provisions for only three positions-chairperson, secretary and treasurer. Most of the organizations had 7 and 5 members of the executive committees, with the least preferred being 4 as TABLE 1.8 below shows.

Figure 1.8: Size of executive committees

\begin{tabular}{|l|l|l|}
\hline No. of Executive Committee Members & Frequency & Percent \\
\hline 4 & 9 & 4 \\
\hline 5 & 73 & 31 \\
\hline 6 & 26 & 11 \\
\hline 7 & 92 & 39 \\
\hline Over 7 & 36 & 15 \\
\hline Total & 236 & 100 \\
\hline
\end{tabular}

4.2.10 Number of Terms Elected Officials Serve: Organizations that held elections of executive committee members annually had $62 \%$ and $38 \%$ preference for no term limits and three terms respectively. Where elections were done bi-annually had $78 \%$ and $24 \%$ of organizations subjecting serving official to 2 terms and no term limits respectively. An election cycle of 4 years was confined to 1 and 2 terms, which represented $51 \%$ and $49 \%$ of organizations surveyed in that order as TABLE 1.9 below shows.

Table 1.9: Distribution of Number of Terms Served by Elected Officials

\begin{tabular}{|cc|c|c|c|c|c|}
\hline & \multicolumn{5}{|c|}{ Number of terms } & \\
\cline { 3 - 6 } & & 1 Term & 2 Terms & 3 Terms & No term limit & Total \\
\hline Election cycle & $1 \mathrm{Yr}$ & - & - & $38 \%$ & $62 \%$ & $100 \%$ \\
& $2 \mathrm{Yrs}$ & - & $78 \%$ & - & $24 \%$ & $100 \%$ \\
& $3 \mathrm{Yrs}$ & $49 \%$ & $22 \%$ & $15 \%$ & $14 \%$ & $100 \%$ \\
& $4 \mathrm{Yrs}$ & $51 \%$ & $49 \%$ & - & - & $100 \%$ \\
\hline
\end{tabular}

4.2.11 Dispute Trends in the Organizations: Fig 1.8 below shows that between 2008 and 2010, many organizations experienced increased incidences of disputes. In the year 2008 , about $27 \%$ of the organizations experienced disputes, with $38 \%$ and $42 \%$ of the organizations experiencing disputes in the year 2009 and 2010 respectively.

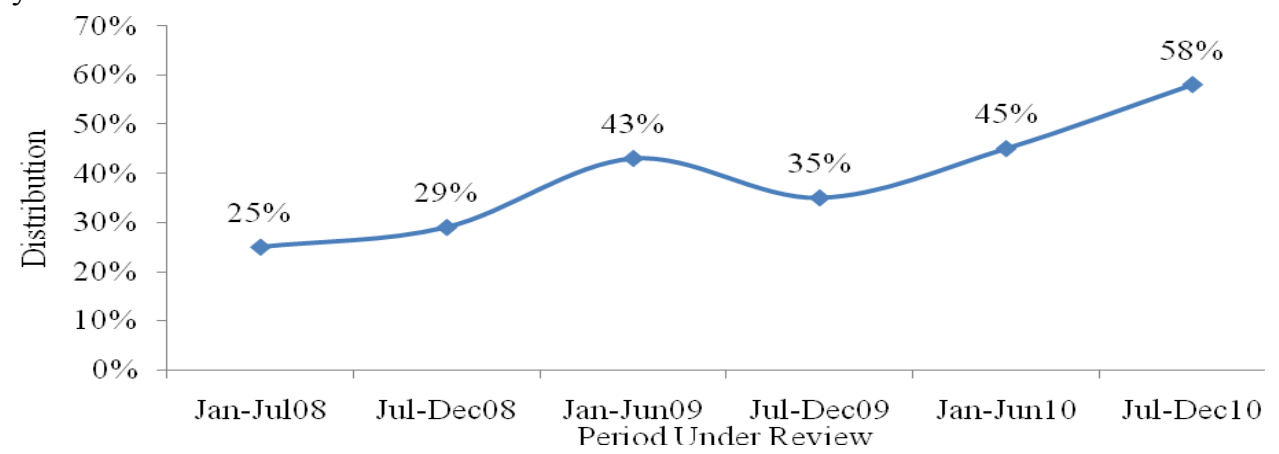

Figure 1.8: Dispute trends in Selected Organizations 
4.2.12 Causes of Disputes in the Organizations: According to TABLE 1.10 below, disputes in self-help organizations were largely caused by misappropriation of funds, lack of participatory management and electoral malpractices, which accounted for $32 \%, 28 \%$ and $24 \%$ of the disputes respectively.

Table 1.10: Distributions of Causes of Disputes

\begin{tabular}{|l|l|r|}
\hline Cause of Dispute & Frequency & Percent \\
\hline Misappropriation of Funds & 76 & $32 \%$ \\
Exclusive Management & 66 & $28 \%$ \\
Electoral Related & 57 & $24 \%$ \\
Others & 37 & $16 \%$ \\
\hline Total & 236 & $100 \%$ \\
\hline
\end{tabular}

4.2.13 Dispute Arbitration: This study did not only determine the dispute resolution institutions, but also their spread within the self-help organizations' sector. DSSOs, chiefs, sponsors, religious leaders and organizational councils handled $59 \%, 26 \%, 7 \%, 45$ and $4 \%$ of disputes in various organizations as TABLE 1.11 below indicates.

Table 1.11: Distribution of Dispute Arbitrators

\begin{tabular}{|l|r|r|}
\hline Arbitrator & Frequency & Percent \\
\hline DSSO/SDA & 140 & 59.3 \\
Chief/Assistant Chief & 61 & 25.8 \\
Sponsor & 17 & 7.2 \\
Religious Leaders & 9 & 3.8 \\
The Council & 9 & 3.8 \\
Total & 236 & 100.0 \\
\hline
\end{tabular}

4.2.14 Consequences of Protracted Disputes: Protracted/unresolved disputes adversely affected organizations. These included declines in membership, organizational split, withholding of funds and even loss of sponsorship as figure 1.12 below.

Table 1.12: Consequences of Unresolved Disputes

\begin{tabular}{|l|l|l|}
\hline Consequence & Frequency & Percent \\
\hline Organization Split & 78 & 33 \\
\hline Membership Decline & 92 & 39 \\
\hline Withholding of Funds & 26 & 11 \\
\hline Loss of Sponsorship & 31 & 13 \\
\hline Others & 9 & 4 \\
\hline Total & 236 & 100 \\
\hline
\end{tabular}

\subsection{Governance Practices and Performance of Self-help Organizations}

Likert scale was used to measure organizational performances, and which was categorized into effectiveness, efficiency and timeliness. Response categories of strongly agreed, agreed, neutral, disagreed or strongly disagreed were used to gauge respondents' perceived groups' effectiveness, efficiency and timeliness. Numericals- $1,2,3,4$, and 5 represented strongly agree, agree, neutral, disagree and strongly disagree in that order. A mean score of 1, 2, 3, 4 and 5 signified excellent, very good, good, average and poor performances respectively. In overall performance, groups had a mean score of 2.97 , which was an average performance. The mean scores for effectiveness, timeliness, and efficiency were 2.69, 2.93 and 3.30 respectively (TABLE 1.13 below).

Table 1.13: Mean Scores of Groups' Performance

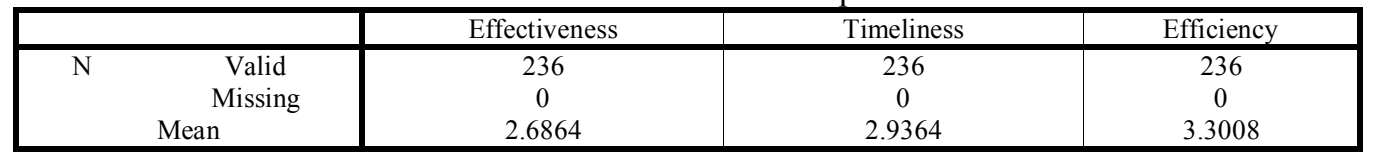

Having established that performances were average, the study proceeded to establish members' opinion on the change self-help work have had on their lives. With three possible outcomes-improved, same and deteriorationon the quality of their lives, $59 \%$ and $41 \%$ of the respondents felt that their lives had improved and remained the same respectively as TABLE 1.14 below shows. 
Table 1.14: Groups' Impact on Members' Quality of Life

\begin{tabular}{|l|l|l|}
\hline Perceived Impact & Frequency & Percent \\
\hline Remained Same & 138 & 41 \\
\hline Improved & 198 & 59 \\
\hline Deterioration & - & - \\
\hline Total & 336 & 100 \\
\hline
\end{tabular}

Given the results in table 1.14 above, it was important to understand what had influenced performance in various groups. Accordingly this study has in the following section examined the relationship between governance practices and self-help organizations' performance. Governance practices examined were size of executive committee, election cycle, numbers of terms by elected officials and incidences of disputes. They were then measured against effectiveness, timeliness and efficiency.

4.3.1 Size of Executive Committee and Performance: There was a significant positive relationship between the size of the executive committee and performance (Effectiveness: $r=0.175, \mathrm{P}=0.000$; Timeliness: $r=0.322$, $\mathrm{P}=0.000$; Efficiency: $r=0.612, \mathrm{P}=0.00$ ). Discussions with respondents revealed that marked performances were in organizations an executive size of between 4 and 5. Poor performances were most noticeable in organizations with an executive size of between 7 and over 7. These findings are consistent with those of [17] and [18] - in Malaysia, which reported a significant relationship between a firm's performance and board size. These scholars found that organizations with relatively small boards showed a marked performance compared to those with large boards. [19] and [20], however, found that performance was more noticeable in firms with larger boards compared to smaller boards. And this they attributed to the ability of larger boards to offer a range of expertise that helps firms make better decisions.

Although the above studies and writings are on corporate organizations they can also apply to other formal organizations such as self-help organizations. Performance was exceptional in organizations with small executive committees, and such good performance was largely due to fewer conflicting views and clear lines of responsibilities. Smaller executive committees also incurred less in co-ordination. Large executive committees were less efficient due to difficulties in solving the agency problem among the members of the committee in addition to having individuals with no ambiguous and overlapping tasks since their inclusion into the committee was motivated more by the desire to massage personal egos.

4.3.2 Election Cycle and Performance: This study found there was a significant but negative relationship between election cycle and organizations' performance (Effectiveness: $\mathrm{r}=-0.101, \mathrm{P}=0.061$; Timeliness: $r=$ $0.187, \mathrm{P}=002$; Efficiency: $r=-0.381, \mathrm{P}=0.000)$. Respondents' accounts showed that election cycle of $2-3$ years inspired impressive performances compared to those of 4 and above years. These findings resonate with other studies- [21], and [22]. [21], for instance found that 3-4 years term legislatures performed better than their 2years term counterparts. Similarly, [22] reported that that organizations with high turnover of directors, occasioned by short-term election cycle, performed poorly compared to those with low turn over of directors.

Periodic elections, which were held after different intervals depending on the organization served as the main instrument through which members held their leaders accountable. Elections also enabled members to selectively retain good incumbents, while constraining opportunistic behaviours. Short term lengths allow for the quick reversal of bad appointments in addition to keeping elected leaders more accountable. Moreover, very frequent elections distract both leaders and members from productive activities as they devote time to election related issues. Poor performance in organizations with election cycle of less than 2 years is here attributed to incomplete socialization of the elected officials, which undermines their performance. Short term election cycle also encourage newly elected leaders to concentrate more on their re-election strategies at the expense of the organization. Newly elected leaders also need time to identify productive and constructive members, allies and even to mobilize essential resources; activities that may not be achieved under short term election cycle. These conditions make short term election cycle an obstacle to performance. Although longer term election cycles are desirable for leadership effectiveness, such effectiveness wane with time as original leadership ideals are abandoned at the alter of survival and self-preservation. It is noted here that a 3 year election cycle, could sufficiently provide newly elected leaders with enough time to socialize into their new roles, articulate and fully implement their vision.

4.3.3 Number of Terms Served By Executive Committees and Performance: The relationship between number of terms served by elected officials and performance was significant and positive (Effectiveness: $r$ $=0.125, \mathrm{P}=0.027$; Timeliness: $r=0.179, \mathrm{P}=0.003$; Efficiency: $\mathrm{r}=0.386, \mathrm{P}=0.0000)$. Exceptional performances were more pronounced in organizations whose officials served for between 2 and 3 terms. However, poor performances were conspicuous in organizations with one term, over three terms and no term limits. These 
findings concurs with those of [23], which found 2-3 term legislators' performances as exceptional unlike their counterparts with one term or over three terms' service. The authors argued that term limits induce elected officials to concentrate on their official responsibilities as re-election insurance.

This study submits that continued stay in the office due to lack of term limits breeds complacency and self-preservation in leadership. Further, prolonged service such as in a no term limit situation denies organizations fresh ideas necessary for change and transformation. No term limit institutions may also breed dictatorial leaders, who often resort to undemocratic means to perpetuate their officialdom. However, a strictly one term limit denies leaders the latitude to improve their skills over time in their positions. This explains the unsatisfactory performance in organizations with one term limits. Term limits also helps organizations in nurturing alternative leadership and succession planning.

4.3.4 Incidences of Disputes and Performance: There was a significant association between incidences of disputes and organizational performance (Effectiveness: $\chi^{2}=18.594, \mathrm{df}=12, \mathrm{p}=0.005$; Timeliness: $\chi^{2}=25.202$, $\mathrm{df}=9, \mathrm{p}=0.000$; Efficiency: $\chi^{2}=30.064, \mathrm{df}=12, \mathrm{p}=0.000$ ). Organizations with frequent disputes exhibited poor performances in all the three dimensions of organizations' performance. Conversely, satisfactory performances were experienced in organizations with fewer incidences of disputes. These results implied that the more the frequency of incidents the lower the organizations' performance. These findings agree with those of [24], which found that incidences of disputes and goal attainment to be significantly associated.

High incidences of disputes are considered here to be a major source of stress among members since it generates strong negative feelings that interfere with team work. It also undermines organizational communication and work coordination, besides contributing to stereotyping. Further, high incidences of disputes divert needed energies from attainments of organizations' goals to unhelpful idle talks, rumours and pursuit of partisan interests. But because conflicts are inevitable part of organizational due to individuals' goals differences, the occurrence of conflict is a matter of when and not if. However, caution should be taken to confine conflicts to functional levels. Fewer incidences of disputes help lay bear previously ignored problems, which without disputes are considered unimportant. Conflicts may thus serve as a catalyst for change and innovation if well managed.

\section{Conclusions}

This study established that governance practices that enhance performance of collective organizations are a reasonable number of members in the executive committee, low levels of disputes, reasonable election cycle and adequate term limits. Organizations that had about 5 members in their executive committees performed better than those with less or over 5 members in the executive committees. Small executive committees allowed for easy building of consensus, while larger ones hindered groups from effectively dealing with urgency problems in addition to creating free-riding and role conflicts, which adversely affected the committees' overall output. Organizations that held elections after between 2 and 3 years, experienced satisfactory performance due to the latitude leaders had to diagnose groups' problems, devise and implement solutions to the problems. Organizations that had between 2-3 elections terms performed better than their counterparts with lesser of more terms. One term leadership was found to be too cautious, a situation that stifled novelty and innovativeness, while leaders in no term limit-organizations tended to be pre-occupied with selfpreservation. Groups that excelled in financial management, participatory management and timely management of conflicts performed better than others. Consequently, the study concludes that good governance through popular election of executive committees, prudential management of groups' resources, and timely management of conflict is not only critical in gaining members' commitment but also successful performance of collective organizations.

\section{References}

[1] Oyugi, O. W. "Decentralized Development Planning and Management in Kenya: An Assessment." In Working with Rural Communities: A Participatory Action Research in Kenya: 27-45 ed. Chitere, O and Mutiso Roberta. Nairobi: Nairobi University Press. (1991).

[2] Masinde, M. R. J. "The Role of Women in Rural Development In Kenya" in Working with Rural Communities: A Participatory Action Research in Kenya: 27-45 ed. Chitere, O and Mutiso Roberta. Nairobi: Nairobi University Press(1991).

[3] Government of Kenya. The population Census Report. (Nairobi: Government Printers. 1999).

[4] Geographic Dimensions Of Well-being: Who and Where are the Poor? Constituency Level Profile. Vol. II. (Nairobi: Government Printers. 2005).

Poverty Reduction Strategy Paper 2000- 20004. (Nairobi: Government Printers. 2000).

[5] Siaya District Development Plan. 1994- 1994. (Nairobi: Government Printers. 1994).

[7] Siaya district Development Plan. 2002- 2008. (Nairobi: Government Printers. 2002)

[8] Siaya District Development Plan. 2008- 2012. (Nairobi: Government Printers. 2008).

[9] Geographic Dimensions Of Well-being: Who and Where are the Poor? Constituency Level Profile. Vol. II. (Nairobi: Government Printers 2008).

[10] Babbie, E. The Practice of Social Research. (Belmont: Wadsworth Publishing Company. 1986). 
[11] Macionis, J. J. Sociology: The Basics. (New Jersey: Prentice Hall. 1998).

[12] Levine, A and Gelles, J. R. Sociology: An Introduction. (Boston: McGraw Hill. 1999).

[13] Jackson, W. Methods: Doing Social Research. (Toronto: Pearson Education, Inc. 2003).

[14] Soy, S.K. The Case Study as a Research Method. Unpublished paper (Accessed at http://www.gslis.utexas.edu/ ssoy/usesusers/1391d1b.htm. on 10/1/09). 1997).

[15] Yamane, T. Statistics, an Introductory Analysis (3rd ed.). (New York: Harper and Row. 1973)

[16] Kombo, K. and Tromp, K. Proposal and Thesis Writing: An Introduction. (Nairobi: Paulines Publications Africa. 2006).

[17] Kyereboah-Coleman and Biekpe, K. The Relationship Between Board Size, Board Composition, Ceo Duality And Firm Performance: Experience From Ghana. University of Stellenbosch Business School (Usb), Cape Town, South Africa (2005)..

[18] Mak, Y.T. and Yuanto, K. Size really matters: Further evidence on the negative relationship between board size and firm value, Working Paper, National University Singapore. (2003).

[19] Raheja, Charu G., Determinants of Board Size and Composition: A Theory of Corporate Boards, The Journal of Financial and Quantitative Analysis 40, 2005, 283-306.

[20] Coles, Jeffrey L., Naveen D. Daniel, and Lalitha Naveen. "Boards: Does one size fit all”, Journal of Financial Economics 87, 2008, 329-356.

[21] Grofman, B. Legislative term limits: public choice perspectives, (Kluwer Academic Publishers.1996).

[22] Warner, J., Watts, R. and Wruck, K. "Stock Prices and Top Management Changes", Journal of Financial Economics 20, 1988, 461492.

[23] Glazer, N and Wattenberg, M "HowWill Term Limits Affect Legislative Work?" in Bernard Grofman (ed.), Legislative Term Limits: Public Choice Perspectives, (Boston, Dordrecht and London: Kluwer Academic, 1996).

[24] Henry O. "Organizational Conflict and its effects on Organizational Performance". Research Journal of Business Management, 2 (1): 2009, 16-24. 